\title{
Yield and quality criteria in organically and conventionally grown tomatoes in Turkey
}

\author{
Ersin Polat ${ }^{1 *} ;$ Halil Demir ${ }^{1} ;$ Fedai Erler ${ }^{2}$ \\ ${ }_{2}^{1}$ Akdeniz University/Faculty of Agriculture - Dept. of Horticulture - 07070 - Antalya - Turkey. \\ ${ }^{2}$ Akdeniz University/Faculty of Agriculture - Dept. of Plant Protection. \\ *Corresponding author <polat@akdeniz.edu.tr>
}

\begin{abstract}
The term 'organically grown food' denotes products that have been produced in accordance with the principles and practices of organic agriculture. The use of alternatives to synthetic fertilizers is an important issue in organic systems. A two-year field experiment to evaluate effects of organic fertilizers on the yield and quality of open field grown tomatoes (Lycopersicon esculentum Mill.) was carried out in Southern Turkey in 2000 and 2001. Combinations of manure, blood flour and micronutrient preparations were used for fertilization, and conventional mineral fertilization was included as the control. Yield did not differ between the fertilization and the Conventional treatments in the first year of the study, but the highest yield was obtained from conventional in the second year. No differences were found between treatments in terms of fruit soluble sugar content or citric acid. The application of organic fertilizers positively affected the micronutritional element content of tomato fruits compared to the conventional treatment. Organic fertilization results in improved yield and fruit quality compared to conventional fertilization. In addition, organic fertilization should be supported in order to facilitate reuse and disposal of organic wastes and to maintain and/or increase soil fertility.
\end{abstract}

Key words: Lycopersicon esculentum, organic growing, conventional growing

\section{Produção e qualidade de tomates cultivados sob sistemas orgânico e convencional na Turquia}

\begin{abstract}
RESUMO: O termo "alimentos cultivados organicamente" denota produtos que tenham sido produzidos em conformidade com os princípios e práticas da agricultura orgânica. $\mathrm{O}$ uso de alternativas para fertilizantes sintéticos é uma questão importante em sistemas orgânicos. Um experimento de campo foi conduzido no sul da Turquia em 2000 e 2001 para avaliar os efeitos da adubação orgânica na produtividade e na qualidade de tomates (Lycopersicon esculentum Mill), cultivados em campo aberto. Combinações de esterco, farinha de sangue e preparações de micronutrientes foram utilizados para a fertilização, e adubações minerais convencionais foram incluídas como controle. A produção não diferiu entre a fertilização e os tratamentos convencionais no primeiro ano do estudo, porém uma maior produtividade foi obtida a partir do sistema convencional, no segundo ano. Não foram encontradas diferenças entre os tratamentos em termos de teor de açúcares solúveis ou ácido cítrico em frutos. A aplicação de fertilizantes orgânicos afetou positivamente o conteúdo dos elementos micronutritionais dos frutos do tomateiro em relação ao tratamento convencional. A adubação orgânica resultou em maior produtividade e qualidade dos frutos, quando comparada à adubação convencional, e deve ser apoiada, a fim de facilitar a reutilização e eliminação de resíduos orgânicos bem como para manter e/ou aumentar a fertilidade do solo.

Palavras-chave: Lycopersicon esculentum, agricultura orgânica, aagricultura convencional
\end{abstract}

\section{Introduction}

In contemporary agriculture, alternative production methods to eradicate or minimize the long-lasting undesired effects of synthetic fertilizers and pesticides are necessary (Altieri and Francis, 1992). The organic agriculture system, accepted by the European Union and the FAO as an alternative system to conventional agriculture, appears to be an environmentally friendly growing system. In simple terms, organic farming is a production system that excludes synthetic inputs when possible and uses external inputs only when the system cannot be sustained by internal recycling (Woodward and Lampkin, 1990). This production method avoids or largely reduces the use of synthetic chemical inputs, such as fertilizers and pesticides, and aims to minimize negative effects on the environment and maintains the biological diversity of the soil (Mäder et al., 2002).

Organic plant products are grown without the aid of synthetic pesticides and largely without the use of readily soluble mineral fertilizers in a setting that includes a diverse range of crop rotations and excessive soil tillage. Sewage sludge and waste compost are not used as fertilizers. Livestock farming is undertaken in line with the needs of the animals; the farm's own feed is used. Organic production may be considered a possible solution to the health and environmental problems that result from synthetic chemical inputs, such as fer- 
tilizers and pesticides (Aksoy, 2001). Many people believe that organic products are healthier than conventionally produced ones and that they are produced in a more environmentally compatible manner (Baade, 1985). In Turkey, organic production in agriculture started in the mid-1980s, and the availability of organically grown products is steadily increasing (Gubbuk et al., 2004). Organic production in Turkey now accounts for roughly $1 \%$ of the total plant production area (Tuik, 2008).

In many literature reviews, the yield and quality of products from conventional and organic agriculture or foods produced with the aid of different fertilizer systems were summarized and evaluated. A brief summary of the results of these studies indicated that the yield and some quality criteria were adversely affected due to a deficiency of organic inputs in conventional growing systems compared to organic production (Blackmer, 1987; Foster et al., 1986). In contrast, Martinia et al. (2004) reported that there was no difference in tomato (Lycopersicon esculentum Mill.) growth or yield between an established organic system and the comparable conventional system. The aim of the present study was to compare the yield, quality and fruit mineral content of organically and conventionally grown tomatoes in an open field setting.

\section{Material and Methods}

Experimental site and crop management

The study was carried out in Antalya ( $36^{\circ} 53^{\prime} \mathrm{N}$; $30^{\circ} 39^{\prime} \mathrm{E}$, altitude $39 \mathrm{~m}$ ), Turkey for two successive years, in 2000 and 2001 . The soil type was a sandy-loam and no fertilizer was applied before the study. The soil characteristics of the study area were as follows: $\mathrm{pH}$ : 7.9, lime: $6.17 \%$, Electric Conductivity: 2.5 mmhos $\mathrm{cm}^{-1}$, organic matter: $1.88 \%$. No cultivation was performed and no fertilizer was applied before the study. The soil was new land and maquis plants were predominant.

Seeds of tomato cv. M74 $\mathrm{F}_{1}$ were sown in seed trays containing a peat and perlite mixture. At the third true leaf stage, the seedlings were transplanted to the soil at a density of 3.125 plants per $\mathrm{m}^{2}$ in double rows $(1 \times 0.6$ $\times 0.4 \mathrm{~m}$ ) in mid-April for all experiments. All plants were irrigated using drip irrigation. As the plants grew, all lateral shoots were manually removed and poles were employed to support single stems. Plants were headed back after six trusses. Fruit was thinned to no more than six fruits per cluster. Tomato cultivation was conducted between April and July in both years.

In the present study, materials permitted by the rules of organic growing were used to fight pests and diseases. Arabic soap (1\%), a bacterial preparation (Bacillus thuringiensis var. kurstaki) and copper chloride were used to combat aphids, caterpillars and tomato diseases, respectively, in the organic plots, whereas synthetic preparations were used in the conventional plots during both growing seasons.

\section{Measurements and statistical analysis}

Five organic materials, Coplex, Ormin K $(35.5 \%$ $\mathrm{K}_{2} \mathrm{O}$ ), Maxicrop, Ko Humax and Kelpak (the last three contain microelements and some organic acids), were tested in different combinations with cattle manure and blood flour $(13 \% \mathrm{~N})$ that were used as base dressing, in the organic plots. Details of selected combinations of application materials are summarized in Table 1. Manure, Ormin $\mathrm{K}$ and blood flour applications were conducted only once before planting. The origins of these materials are as follows: cattle manure from a local farmer; blood flour from ANET Anon. Comp.; Ormin $\mathrm{K}$ and Coplex from ELIT Ltd. Comp.; Ko Humax, Kelpak and Maxicrop from Koyuncular Ltd. Comp. The composition and the amount of some macro and micro nutrient contents of all the materials tested are given in Table 2. The choice of organic fertilizers in the study and the amounts used were based on previous studies (Gunay, 1992; Vural et al., 2000).

All the fertilizers were incorporated into the top 5 $\mathrm{cm}$ of soil. During the application of fertilizers at both organic and conventional plots, tomato yield per ha and available nutrient levels in the soil were taken into consideration. The fertilization was applied at a rate of 200 $\mathrm{kg} \mathrm{ha}{ }^{-1} \mathrm{~N}, 100 \mathrm{~kg} \mathrm{ha}^{-1} \mathrm{P}_{2} \mathrm{O}_{5}$ and $200 \mathrm{~kg} \mathrm{ha}^{-1} \mathrm{~K}_{2} \mathrm{O}$ (Gunay, 1992; Vural et al., 2000).

All fruits were harvested at light-red stage, and samples were analyzed for total mineral matter. Analyses were carried out according to the method described by Kacar (1995), and the amounts of $\mathrm{K}, \mathrm{Ca}, \mathrm{Na}, \mathrm{Mg}, \mathrm{Mn}$,

Table 1 - Combinations of application materials used in the study over a two year period.

\begin{tabular}{|c|c|}
\hline COP & $\begin{array}{l}\text { Manure }\left(50 \mathrm{t} \mathrm{ha}^{-1}\right) \text {, Ormin } \mathrm{K}\left(1.33 \mathrm{~kg} \mathrm{ha}^{-1}\right) \text {, Blood flour }\left(2.92 \mathrm{~kg} \mathrm{ha}^{-1}\right)+\text { Coplex }\left(700 \mathrm{~kg} \mathrm{ha}^{-1} \text {, given equally }\right. \\
\text { at weekly periods) }\end{array}$ \\
\hline MAX & $\begin{array}{l}\text { Manure }\left(50 \mathrm{t} \mathrm{ha}^{-1}\right) \text {, Ormin } \mathrm{K}\left(1.48 \mathrm{~kg} \mathrm{ha}^{-1}\right) \text {, Blood flour }\left(3.2 \mathrm{t} \mathrm{ha}^{-1}\right)+\text { Maxicrop }\left(25 \mathrm{~kg} \mathrm{ha}^{-1} \text {, five applications }\right. \\
\text { were made once every two weeks) }\end{array}$ \\
\hline $\mathrm{KO}-\mathrm{HU}$ & $\begin{array}{l}\text { Manure }\left(50 \mathrm{t} \mathrm{ha}^{-1}\right) \text {, Ormin } \mathrm{K}\left(1.48 \mathrm{~kg} \mathrm{ha}^{-1}\right) \text {, Blood flour }\left(3.2 \mathrm{t} \mathrm{ha}^{-1}\right)+\mathrm{Ko} \text { Humax }\left(30 \mathrm{~L} \mathrm{ha}^{-1} \text { five }\right. \\
\text { applications were made once every two weeks) }\end{array}$ \\
\hline KEL & $\begin{array}{l}\text { Manure }\left(50 \mathrm{t} \mathrm{ha}^{-1}\right) \text {, Ormin } \mathrm{K}\left(1.48 \mathrm{~kg} \mathrm{ha}^{-1}\right) \text {, Blood flour }\left(3.2 \mathrm{t} \mathrm{ha}^{-1}\right)+\text { Kelpak (156 L ha } \mathrm{L}^{-1} \text {, five applications } \\
\text { were made once every two weeks) }\end{array}$ \\
\hline ORM & $\begin{array}{l}\text { Manure }\left(50 \mathrm{t} \mathrm{ha}^{-1}\right) \text {, Ormin } \mathrm{K}\left(480 \mathrm{~kg} \mathrm{ha}^{-1}\right) \text {, Blood flour }\left(3.2 \mathrm{t} \mathrm{ha}^{-1}\right)+\text { Ormin } \mathrm{K}\left(1.00 \mathrm{~kg} \mathrm{ha}^{-1} \text {, given equally }\right. \\
\text { at weekly periods) }\end{array}$ \\
\hline Conventional & $\begin{array}{l}\text { Manure }\left(50 \mathrm{t} \mathrm{ha}^{-1}\right) \text {, Triple super phosphate, } 260 \mathrm{~kg} \mathrm{ha}^{-1} \text {; ammonium nitrate, } 660 \mathrm{~kg} \mathrm{ha}^{-1} \text {, given equally at } \\
\text { weekly periods; potassium nitrate, } 1,13 \mathrm{~kg} \mathrm{ha}^{-1} \text {, given equally at weekly periods) }\end{array}$ \\
\hline
\end{tabular}


Table 2 - The composition and the amount of some macro and micronutrient contents of the materials tested.

\begin{tabular}{|c|c|c|c|c|c|c|c|}
\hline \multirow{2}{*}{ Organic substance } & Blood flour & Cattle manure & Coplex & Maxicrop & Ko Humax & Kelpak & Ormin $\mathrm{K}$ \\
\hline & & $25 \%$ & $50 \%$ & & & & $8 \%$ \\
\hline $\mathrm{N}$ & $12.94 \%$ & & $3.5 \%$ & $0.75 \%(\mathrm{w} / \mathrm{w})$ & $1.02 \%$ & & $1.20 \%$ \\
\hline $\mathrm{P}_{2} \mathrm{O}_{5}$ & $0.15 \%$ & $655 \mathrm{mg} \mathrm{kg}^{-1}$ & $0.1 \%$ & $0.05 \%(\mathrm{w} / \mathrm{w})$ & $0.03 \%$ & & $0.05 \%$ \\
\hline $\mathrm{K}_{2} \mathrm{O}$ & $1.41 \%$ & $7.75 \mathrm{mg} \mathrm{kg}^{-1}$ & $7.5 \%$ & $19.28 \%(w / w)$ & $18.73 \%$ & & $35.50 \%$ \\
\hline $\mathrm{Ca}$ & $1.20 \%$ & $1.90 \mathrm{mg} \mathrm{kg}^{-1}$ & $1.0 \%$ & $0.35 \%(\mathrm{w} / \mathrm{w})$ & & & $3 \%$ \\
\hline $\mathrm{Cu}$ & $24 \mathrm{mg} \mathrm{kg}^{-1}$ & & $0.5 \mathrm{mg} \mathrm{kg}^{-1}$ & $12 \mathrm{mg} \mathrm{kg}^{-1}$ & $3 \mathrm{mg} \mathrm{kg}^{-1}$ & & $6 \mathrm{mg} \mathrm{kg}^{-1}$ \\
\hline $\mathrm{Mn}$ & $65.60 \mathrm{mg} \mathrm{kg}^{-1}$ & & $40 \mathrm{mg} \mathrm{kg}^{-1}$ & $6 \mathrm{mg} \mathrm{kg}^{-1}$ & $6 \mathrm{mg} \mathrm{kg}^{-1}$ & & $34 \mathrm{mg} \mathrm{kg}^{-1}$ \\
\hline $\mathrm{Fe}$ & $631.4 \mathrm{mg} \mathrm{kg}^{-1}$ & & $80 \mathrm{mg} \mathrm{kg}^{-1}$ & $290 \mathrm{mg} \mathrm{kg}^{-1}$ & $30.80 \mathrm{mg} \mathrm{kg}^{-1}$ & & $60 \mathrm{mg} \mathrm{kg}^{-1}$ \\
\hline $\mathrm{Zn}$ & $143.4 \mathrm{mg} \mathrm{kg}^{-1}$ & & $60 \mathrm{mg} \mathrm{kg}^{-1}$ & $56 \mathrm{mg} \mathrm{kg}^{-1}$ & $6 \mathrm{mg} \mathrm{kg}^{-1}$ & & $7 \mathrm{mg} \mathrm{kg}^{-1}$ \\
\hline $\mathrm{Mg}$ & $0.37 \%$ & $2132 \mathrm{mg} \mathrm{kg}^{-1}$ & $0.1 \%$ & $0.20 \%(w / w)$ & $331 \mathrm{mg} \mathrm{kg}^{-1}$ & & $1 \%$ \\
\hline S & & & $1.0 \%$ & $2.90 \%(w / w)$ & $28.51 \mathrm{mg} \mathrm{kg}^{-1}$ & & $31.50 \%$ \\
\hline Mo & & & $0.6 \mathrm{mg} \mathrm{kg}^{-1}$ & $2 \mathrm{mg} \mathrm{kg}^{-1}$ & $0.40 \mathrm{mg} \mathrm{kg}^{-1}$ & & $0.5 \mathrm{mg} \mathrm{kg}^{-1}$ \\
\hline B & & & $10 \mathrm{mg} \mathrm{kg}^{-1}$ & $30 \mathrm{mg} \mathrm{kg}^{-1}$ & $2.90 \mathrm{mg} \mathrm{kg}^{-1}$ & & \\
\hline Humic acid & & & & & $55 \%$ & & \\
\hline Fulvic acid & & & & & $30 \%$ & & \\
\hline Natural oxins & & & & & & $11 \mathrm{mg} \mathrm{L}^{-1}$ & \\
\hline Natural cytocinins & & & & & & $0.031 \mathrm{mg} \mathrm{L}^{-1}$ & \\
\hline
\end{tabular}

$\mathrm{Fe}, \mathrm{Zn}$ and $\mathrm{Cu}$ in each sample were determined in an atomic absorption spectrophotometer. Soluble sugars ( ${ }^{\circ}$ Brix), vitamin $\mathrm{C}\left(\mathrm{mg} 100 \mathrm{~mL}^{-1}\right)$, citric acid $\left(\mathrm{g} 100 \mathrm{~mL}^{-1}\right)$, $\mathrm{pH}$ (juice content), total yield $\left(\mathrm{kg} \mathrm{ha}^{-1}\right)$, firmness $(\mathrm{MPa})$, fruit flesh thickness $(\mathrm{mm})$ and some micronutrition elements were measured in tomato fruit. The fruit samples from each treatment ( 10 per replicate; 30 per treatment) were minced in a blender, and the content of soluble sugars in the juice of fruit samples was measured using a refractometer. Ascorbic acid was extracted in $1 \%$ oxalic acid and measured using reflectoquant ascorbic acid test strips in an Rqflex reflectometer. The $\mathrm{pH}$ of fruit juice samples was determined in a $50 \mathrm{~mL}$ filtrate obtained from a mixture of $10 \mathrm{~g}$ of material blended in 100 $\mathrm{mL}$ of deionized water. Surface color characteristics, L (brightness), a (red component), b (yellow component) and hue $\left[\tan ^{-1}(\mathrm{~b} / \mathrm{a})\right]$, were determined using a colorimeter in triplicate for each fruit. Average citric acid contents of the fruit juice samples were determined by titration of a $2 \mathrm{~mL}$ sample with $0.1 \mathrm{~mol} \mathrm{~L}^{-1} \mathrm{NaOH}$. Firmness was determined with a manual penetrometer with a cylindrical embolus of $11 \mathrm{~mm}$ diameter. Fruit shape was also determined by dividing the equatorial (E) and the longitudinal (L) diameter. Flesh thickness was measured using a digital caliper. Monthly average rainfall and temperature data pertaining to the years 2000 and 2001 were obtained from a local meteorological station near the study area and are presented in Figure 1. The region is characterized by a Mediterranean climate. The total rainfall and mean temperature during the experimental period (from April to July) were $189.4 \mathrm{~mm}$ and $23.7^{\circ} \mathrm{C}$, respectively, in 2000 , and $159.7 \mathrm{~mm}$ and $23.1^{\circ} \mathrm{C}$, respectively, in 2001 (Figure 1).

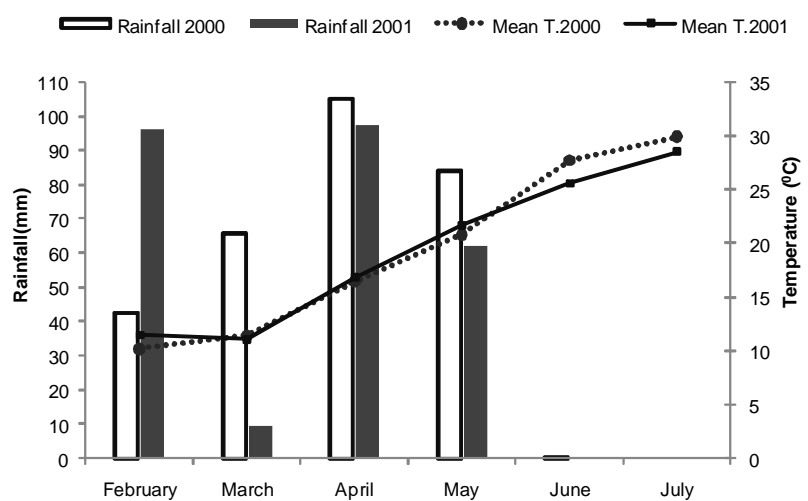

Figure 1 - Monthly values of rainfall and temperature during the study period, from 2000 to 2001 (Data were obtained from a local meteorological station near the study area).

The experimental design was completely randomized with three replications. Each experimental replication consisted of 18 plants. Analysis of variance was performed using the COSTAT statistical program (CoHort software, version 6.303), and means were compared using the LSD test at $p \leq 0.05$.

\section{Results}

No differences were observed in total yield, fruit shape, firmness or fruit flesh thickness between the treatments during the first year. Total yield and fruit flesh thickness varied between the treatment groups during the second year $(p \leq 0.05)$. In this year, the highest yields were recorded in the Conventional and KO-HU treatments as compared with the others (Table 3). L, b and 
the hue of the tomato fruits in the first year was found to be higher following various organic fertilizer treatments as compared with the conventional $(p \leq 0.05)$ (Table 4). However, there were no differences in L, a, b or hue of tomato fruits during the second year.

During the first year, the vitamin $\mathrm{C}$ content of tomato fruits was higher in all treatments except of COP application. The tomato fruits from the $\mathrm{KO}-\mathrm{HU}$ treatment group had the highest vitamin $\mathrm{C}$ content compared to all others $(p \leq 0.05)$. However, there were no differences in soluble sugar, $\mathrm{pH}$ of juice, or citric acid in either year or vitamin $\mathrm{C}$ in the second year between the treatments (Table 5). K, Na, Ca, Cu, $\mathrm{Zn}$ and Fe contents of fruits were influenced by various organic fertilizers (Table 6). Conversely, no differences were found in $\mathrm{Mg}$ or $\mathrm{Mn}$ content of tomato fruits grown with different treatments. The mineral content of fruits was not lower in organic treatment groups as compared with the Conventional. In particular, the ORM treated fruits had higher $\mathrm{Zn}$ and Fe contents than those treated with other materials (Table 6).

\section{Discussion}

The total yield in the second year of the study was affected by application of the test materials. In contrast, no differences were found between the treatments tested in the first year. We surmise that these differences resulted from climatic conditions (Figure 1) because the temperature in early summer in the second year was lower approximately $2^{\circ} \mathrm{C}$ compared to the first year. It is generally supposed that lower temperature may result in lower intake of organic fertilizers. The highest yields in the second year were obtained from the treatment with humic substance, Ko Humax, and the Conventional. Chen and Aviad (1990) reported results similar to our second year findings in a previous study on the effects of humic substances on plant growth. Atiyeh et al. (2002) reported that some growth responses were likely due to hormone-like activities of humic acids from the vermicomposts or due to plant growth hormones adsorbed by the humates, which were obtained from tomato and cucumber.

External color was expressed in terms of hue angle, which is considered to be the most important measure of the visual perception of tomato quality (Shewfelt and Prussia, 1993), because external fruit color relates better to perception of color by the human eye. When hue angle increases, the color changes from red to orange. In our study, tomato color was measured at three locations on the tomato surface, including the bottom,

Table 3 - Effect of various organic fertilizers on total yield and appearance of tomato fruits.

\begin{tabular}{|c|c|c|c|c|c|c|c|c|}
\hline \multirow{2}{*}{ Treatment } & \multicolumn{2}{|c|}{ Total yield } & \multicolumn{2}{|c|}{ Shape } & \multicolumn{2}{|c|}{ Firmness } & \multicolumn{2}{|c|}{ Fruit flesh thickness } \\
\hline & $1^{\text {st }}$ year & $2^{\text {nd }}$ year & $1^{\text {st }}$ year & $2^{\text {nd }}$ year & $1^{\text {st }}$ year & $2^{\text {nd }}$ year & $1^{\text {st }}$ year & $2^{\text {nd }}$ year \\
\hline & \multicolumn{2}{|c|}{ kg ha-1 } & \multicolumn{2}{|c|}{$\mathrm{E} / \mathrm{L} *$} & \multicolumn{2}{|c|}{$\mathrm{MPa}$} & \multicolumn{2}{|c|}{ mm - } \\
\hline COP & $75360 \mathrm{a}$ & $87970 a b^{I}$ & 1.18 a & $1.20 \mathrm{a}$ & $0.020 \mathrm{a}$ & $0.009 a$ & $8.48 \mathrm{a}$ & $8.20 \mathrm{ab}$ \\
\hline MAX & $73550 \mathrm{a}$ & $80260 \mathrm{c}$ & $1.14 \mathrm{a}$ & $1.18 \mathrm{a}$ & $0.021 \mathrm{a}$ & $0.009 a$ & $8.44 \mathrm{a}$ & $7.90 \mathrm{c}$ \\
\hline $\mathrm{KO}-\mathrm{HU}$ & $77050 \mathrm{a}$ & $92000 \mathrm{a}$ & $1.15 \mathrm{a}$ & $1.19 \mathrm{a}$ & $0.019 a$ & $0.010 \mathrm{a}$ & $8.21 \mathrm{a}$ & $7.80 \mathrm{c}$ \\
\hline KEL & 77940 a & 83440 bc & $1.12 \mathrm{a}$ & $1.22 \mathrm{a}$ & $0.019 a$ & $0.010 \mathrm{a}$ & $8.29 \mathrm{a}$ & $8.30 \mathrm{a}$ \\
\hline ORM & $71340 \mathrm{a}$ & $83320 \mathrm{bc}$ & $1.13 \mathrm{a}$ & $1.19 \mathrm{a}$ & $0.018 \mathrm{a}$ & $0.009 a$ & $8.01 \mathrm{a}$ & $8.00 \mathrm{bc}$ \\
\hline Conventional & 74170 a & $91400 \mathrm{a}$ & $1.15 \mathrm{a}$ & $1.18 \mathrm{a}$ & $0.019 a$ & $0.009 a$ & $8.51 \mathrm{a}$ & $7.90 \mathrm{c}$ \\
\hline $\mathrm{LSD}_{\% 5}$ & 6605 & 6524 & 0.08 & 0.06 & 0.003 & 0.001 & 0.52 & 0.28 \\
\hline
\end{tabular}

"E/L: the equatorial (E) and the longitudinal (L) diameter), ${ }^{\mathrm{I}}$ Values within columns followed by different letters are significantly different $(p \leq 0.05)$ according to the LSD test.

Table 4 - Effect of organic fertilizers on $\mathrm{L}, \mathrm{a}, \mathrm{b}$ and hue angle $\left(^{\circ}\right)$ of tomato fruits.

\begin{tabular}{|c|c|c|c|c|c|c|c|c|}
\hline \multirow{2}{*}{ Treatment } & \multicolumn{2}{|c|}{$\mathrm{L}$} & \multicolumn{2}{|c|}{$\mathrm{a}^{1}$} & \multicolumn{2}{|c|}{$b^{1}$} & \multicolumn{2}{|c|}{$h_{u e^{\circ}}$} \\
\hline & $1^{\text {st }}$ year & $2^{\text {nd }}$ year & $1^{\text {st }}$ year & $2^{\text {nd }}$ year & $1^{\text {st }}$ year & $2^{\text {nd }}$ year & $1^{\text {st }}$ year & $2^{\text {nd }}$ year \\
\hline & & & & & & & \multicolumn{2}{|c|}{$\tan ^{-1}(b / a)$} \\
\hline COP & $38.29 \mathrm{ab}^{\mathrm{I}}$ & $39.78 \mathrm{a}$ & $32.29 \mathrm{a}$ & $31.30 \mathrm{a}$ & $27.63 \mathrm{ab}$ & $25.88 \mathrm{a}$ & $40.55 \mathrm{ab}$ & $39.58 \mathrm{a}$ \\
\hline MAX & $38.79 \mathrm{a}$ & $40.35 \mathrm{a}$ & $32.90 \mathrm{a}$ & $31.14 \mathrm{a}$ & $28.64 \mathrm{a}$ & $25.06 \mathrm{a}$ & $41.04 \mathrm{a}$ & $38.82 \mathrm{a}$ \\
\hline $\mathrm{KO}-\mathrm{HU}$ & $38.22 \mathrm{ab}$ & $40.83 \mathrm{a}$ & $32.53 \mathrm{a}$ & $31.22 \mathrm{a}$ & $26.93 \mathrm{bc}$ & $25.29 \mathrm{a}$ & $39.61 \mathrm{bc}$ & $39.00 \mathrm{a}$ \\
\hline KEL & 38.66 a & 40.27 a & $32.63 \mathrm{a}$ & $31.46 \mathrm{a}$ & $28.07 \mathrm{a}$ & $26.42 \mathrm{a}$ & $40.70 \mathrm{ab}$ & $40.02 \mathrm{a}$ \\
\hline ORM & 38.89 a & 39.82 a & $31.95 \mathrm{a}$ & $31.57 \mathrm{a}$ & $28.01 \mathrm{a}$ & $25.70 \mathrm{a}$ & $41.24 \mathrm{a}$ & $39.14 \mathrm{a}$ \\
\hline Conventional & $37.67 \mathrm{~b}$ & $40.49 \mathrm{a}$ & $32.46 \mathrm{a}$ & $30.53 \mathrm{a}$ & $26.51 \mathrm{c}$ & $25.21 \mathrm{a}$ & $39.23 \mathrm{c}$ & $39.54 \mathrm{a}$ \\
\hline $\mathrm{LSD}_{\% 5}$ & 0.70 & 1.07 & 0.97 & 1.06 & 1.05 & 1.38 & 1.25 & 1.27 \\
\hline
\end{tabular}

${ }^{\mathrm{I}}$ Values within columns followed by different letters are different (LSD test, $\left.p \leq 0.05\right)$. $\mathrm{a}^{1}$ - red component; $\mathrm{b}^{1}-\mathrm{yellow}$ component; $\mathrm{L}$ - brightness; hue - hue angle, $\mathrm{h}=\operatorname{arctg} \mathrm{b} / \mathrm{a}$. 
Table 5 - Effect of organic fertilizers on soluble sugar content, $\mathrm{pH}$, citric acid content and vitamin $\mathrm{C}$ content of tomato fruits.

\begin{tabular}{|c|c|c|c|c|c|c|c|c|}
\hline \multirow{2}{*}{ Treatment } & \multicolumn{2}{|c|}{ Soluble sugars } & \multicolumn{2}{|c|}{$\mathrm{pH}$ of juice } & \multicolumn{2}{|c|}{ Citric acid } & \multicolumn{2}{|c|}{ Vitamin C } \\
\hline & $1^{\text {st }}$ year & $2^{\text {nd }}$ year & $1^{\text {st }}$ year & $2^{\text {nd }}$ year & $1^{\text {st }}$ year & $2^{\text {nd }}$ year & $1^{\text {st }}$ year & $2^{\text {nd }}$ year \\
\hline & \multicolumn{2}{|c|}{${ }^{\circ}$ Brix } & & & \multicolumn{2}{|c|}{ g $100 \mathrm{~mL}^{-1}$} & \multicolumn{2}{|c|}{ mg $100 \mathrm{~mL}^{-1}$} \\
\hline COP & $4.53 \mathrm{a}$ & $5.0 \mathrm{a}$ & $4.47 \mathrm{a}$ & $4.38 \mathrm{a}$ & $0.34 \mathrm{a}$ & $0.70 \mathrm{a}$ & $27.73 c^{I}$ & $29.24 \mathrm{a}$ \\
\hline MAX & $4.40 \mathrm{a}$ & $4.76 \mathrm{a}$ & $4.45 \mathrm{a}$ & $4.36 \mathrm{a}$ & $0.36 \mathrm{a}$ & $0.77 \mathrm{a}$ & $29.77 a b c$ & $28.91 \mathrm{a}$ \\
\hline $\mathrm{KO}-\mathrm{HU}$ & $4.42 \mathrm{a}$ & $4.73 \mathrm{a}$ & $4.45 \mathrm{a}$ & $4.40 \mathrm{a}$ & $0.33 \mathrm{a}$ & $0.74 \mathrm{a}$ & $31.17 \mathrm{a}$ & $30.02 \mathrm{a}$ \\
\hline KEL & $4.56 \mathrm{a}$ & $4.84 \mathrm{a}$ & $4.52 \mathrm{a}$ & $4.38 \mathrm{a}$ & $0.35 \mathrm{a}$ & $0.68 a$ & $30.24 \mathrm{ab}$ & $29.01 \mathrm{a}$ \\
\hline ORM & $4.40 \mathrm{a}$ & $4.96 \mathrm{a}$ & $4.45 \mathrm{a}$ & $4.38 \mathrm{a}$ & $0.35 \mathrm{a}$ & $0.74 \mathrm{a}$ & $28.26 \mathrm{bc}$ & $28.17 \mathrm{a}$ \\
\hline Conventional & $4.58 \mathrm{a}$ & $4.82 \mathrm{a}$ & $4.48 \mathrm{a}$ & $4.36 \mathrm{a}$ & $0.34 \mathrm{a}$ & $0.78 \mathrm{a}$ & $30.20 \mathrm{ab}$ & $29.52 \mathrm{a}$ \\
\hline $\mathrm{LSD}_{\% 5}$ & 0.19 & 0.28 & 0.09 & 0.06 & 0.05 & 0.17 & 2.19 & 1.89 \\
\hline
\end{tabular}

IValues within columns followed by different letters are different (LSD test, $p \leq 0.05$ ).

Table 6 - Effect of organic fertilizers on the micronutrition element content of tomato fruits as an average of two years.

\begin{tabular}{lcccccccc}
\hline & $\mathrm{K}$ & $\mathrm{Na}$ & $\mathrm{Mg}$ & $\mathrm{Ca}$ & $\mathrm{Cu}$ & $\mathrm{Zn}$ & $\mathrm{Mn}$ & $\mathrm{Fe}$ \\
\hline & $1461 \mathrm{c}^{\mathrm{I}}$ & $17.26 \mathrm{a}$ & $89.81 \mathrm{a}$ & $103.41 \mathrm{~b}$ & $1.58 \mathrm{a}$ & $1.33 \mathrm{~b}$ & $1.17 \mathrm{a}$ & $2.28 \mathrm{~b}$ \\
COP & $1580 \mathrm{a}$ & $15.10 \mathrm{~b}$ & $89.85 \mathrm{a}$ & $109.95 \mathrm{a}$ & $1.30 \mathrm{~b}$ & $1.34 \mathrm{~b}$ & $1.15 \mathrm{a}$ & $2.07 \mathrm{~b}$ \\
MAX & $1544 \mathrm{ab}$ & $17.27 \mathrm{a}$ & $88.58 \mathrm{a}$ & $104.59 \mathrm{~b}$ & $1.33 \mathrm{~b}$ & $1.28 \mathrm{~b}$ & $1.14 \mathrm{a}$ & $2.25 \mathrm{~b}$ \\
KO-HU & $1470 \mathrm{c}$ & $16.84 \mathrm{a}$ & $89.84 \mathrm{a}$ & $102.91 \mathrm{~b}$ & $1.30 \mathrm{~b}$ & $1.26 \mathrm{~b}$ & $1.14 \mathrm{a}$ & $2.03 \mathrm{~b}$ \\
KEL & $1502 \mathrm{bc}$ & $17.42 \mathrm{a}$ & $92.08 \mathrm{a}$ & $109.32 \mathrm{a}$ & $1.36 \mathrm{~b}$ & $1.68 \mathrm{a}$ & $1.20 \mathrm{a}$ & $3.05 \mathrm{a}$ \\
ORM & $1558 \mathrm{ab}$ & $17.32 \mathrm{a}$ & $88.69 \mathrm{a}$ & $105.86 \mathrm{ab}$ & $1.14 \mathrm{c}$ & $1.32 \mathrm{~b}$ & $1.15 \mathrm{a}$ & $2.33 \mathrm{~b}$ \\
Conventional & 66.02 & 0.74 & 3.72 & 4.44 & 0.14 & 0.21 & 0.08 & 0.34 \\
LSD $_{\% 5}$ & & &
\end{tabular}

${ }^{\mathrm{I}}$ Values within columns followed by different letters are different (LSD test, $p \leq 0.05$ ).

middle and top of the fruit. In the first year, the color at the red stage was less intense in tomatoes exposed to organic treatments compared to those from the Conventional group (Table 4). These variations could have been the consequence of meteorological factors (Figure 1), such as temperature, sunshine and rainfall during growth and ripening (Markus et al., 1999), and could also be attributed to the applied agricultural conditions, such as the removal of leaves damaged by pests and diseases as a result of not using any chemicals, in accordance with the rules of organic management. However, no differences in terms of hue angle were observed between the treatments. This might have resulted from the use of some organic pesticides in pest management. As a result, the leaves were healthier than those in the first year of the study. As for the effects of the treatments on $\mathrm{L}$ values of tomato fruits, all the above-mentioned reasons are valid explanations for the $\mathrm{L}$ values observed (Figure 1). Our results agree with those of Garcia and Barrett (2006).

Soluble sugar contents, $\mathrm{pH}$ and citric acid levels of tomato fruits were not affected by the different treatments in either year of the study. Similar results were observed by Polat et al. (2008) who found that the effects of various organic fertilizer applications on soluble solids, ascorbic acid contents and $\mathrm{pH}$ in Iceberg type lettuce. In the second year results, there were no differ- ences among the applications on ascorbic acid and $\mathrm{pH}$ in Iceberg type lettuce. On the other hand, in both years, the effects of soluble solids and in the first year ascorbic acid and $\mathrm{pH}$ in Iceberg type lettuce growing on applications were significant. Our results are similar to those of Rinaldi et al. (2007) who reported that treatments with organic fertilizers had no effect on soluble solid content or the level of citric acid in tomato fruits. In the present study, vitamin $\mathrm{C}$ content in the first year was highest in the KO-HU, KEL, Conventional and MAX-fertilized tomatoes, but no differences were found among the treatments in the second year of the study. Similar results were found by Dumas et al. (2003) who reported that the vitamin $\mathrm{C}$ contents in the organic or ammonium-fertilized tomatoes in the first year of study were highest, while the contents were lowest in nitratefertilized tomatoes. In the second year of the study, the results were contrary.

$\mathrm{Cu}, \mathrm{Zn}$ and $\mathrm{Fe}$ micronutrient contents of tomato fruits were altered by treatments with various organic fertilizers. Excepti for $\mathrm{Mg}$ and $\mathrm{Mn}$, there were differences among all the treatments in terms of mineral element contents ( $p \leq 0.05$, Table 6). Na content in MAX-treated tomatoes was lower than all others treatments tested, while the $\mathrm{Fe}$ and $\mathrm{Zn}$ contents in the ORM-treated tomatoes were higher than the others $(p \leq 0.05)$. The $\mathrm{Cu}$ content was highest in COP-treated tomatoes but lowest in 
Conventional tomatoes. While the highest $\mathrm{Ca}$ contents were found in MAX and ORM, the highest $\mathrm{K}$ contents were found in MAX. This relationship could be attributed to the higher amounts of some nutritional elements in organic substances relative to substances used in the Conventional group. The same relationship was observed by Thybo et al. (2006); however, they reported a slight increase in the content of nutritional elements for tomatoes grown in combined growing systems (integration of organic and conventional treatments) compared to any individual system. Polat et al. (2008) evaluated the effects of the same organic fertilizer tested in the present study on some micro-nutrition in Iceberg type lettuce leaves were investigated. The effects of Ko humax, Maxicrop, Kelpak applications on the contents of $\mathrm{Ca}$, $\mathrm{Na}$ and $\mathrm{Fe}$ in lettuce leaves were significant, respectively. In conclusion, organic fertilization showed promising results in terms of total yield and fruit quality compared to conventional fertilization.

\section{Acknowledgements}

To the Scientific Projects Administration Unit of Akdeniz University for supplying financial support and to the anonymous reviewer for her invaluable comments and suggestions.

\section{References}

Aksoy, U. 2001. Ecological agriculture: a general view. p. 3-10. In: Ozturk, A.; Akkaya, F., ed. 2001. Proceedings of the Symposium on Ecological Agriculture. The Turkish Agricultural Society, Antalya, Turkey.

Altieri, M.A.; Francis, A.C. 1992. Incorporating agroecology into the conventional agricultural curriculum. American Journal of Alternative Agriculture 7: 89-92.

Atiyeh, R.M.; Lee, S.; Edwards, C.A.; Arancon, N.Q.; Metzger, J.D. 2002. The influence of humic acids derived from earthwormprocessed organic wastes on plant growth. Bioresource Technology 84: 7-14.

Baade, E. 1985. Einstellungen und Verhaltensweisen bei Verbrauchern von "Bio'-Produkten. AID-Verbrauch 30: 245253.

Blackmer, A.M. 1987. Losses and transport of nitrogen from soils. p. 85-103. In: D'itri, F.M.; Wolfson, L.G., eds. Rural groundwater contamination. Lewis Publishers, Chelsea, UK.

Chen, Y.; Aviad, T. 1990. Effects of humic substances on plant growth. p. 161-186. In: Maccarthy, P.; Clapp, C.E.; Malcolm, R.L.; Bloom, P.R., eds. Humic substances in soil and crop sciences: selected readings. Madison Press, Madison, WI, USA.
Dumas, Y.; Dadomo, M.; Di lucca, G.; Grolier, P. 2003. Effects of environmental factors and agricultural techniques on antioxidant content of tomatoes. Journal of Science and Food Agriculture 83: 369-382.

Foster, S.S.D.; Bridge, L.R.; Geake, A.K.; Lowrence, A.R.; Parker, J.M. 1986. The groundwater nitrate problem: a summary of research on the impact of agricultural land-use practices on groundwater quality between 1976 and 1985. Hydrogeology Reports n.86/2.

Garcia, E.; Barrett, D.M. 2006. Evaluation of processing tomatoes from two consecutive growing seasons: quality attributes, peelability and yield. Journal of Food Process and Preservation 30: 20-36.

Gubbuk, H.; Polat, E.; Pekmezci, M. 2004. Organic fruit production in Turkey: orchard management in sustainable fruit production. Journal of Fruit Ornamental Plant Research 12: 23-29.

Gunay, A. 1992. Vegetable Growing. Ankara University Press, Ankara, Turkey.

Kacar, B. 1995. Analyses of Plant and Soil. Ankara University Press, Ankara, Turkey.

Mäder, P.; Fliessbach, A.; Dubois, D.; Gunst, L.; fried, P.; Niggli, U. 2002. Soil fertility and biodiversity in organic farming. Science 296: 1694-1697.

Markus, F.; Daood, H.G.; Kapitány, J.; Biach, P.A. 1999. Change in the carotenoid and antioxidant content of spice red pepper (paprika) as a function of ripening and some technological factors. Journal of Agricultural and Food Chemistry 47: 100107.

Martinia, E.A.; Buyer, J.S.; Bryanta, D.C.; Hartzc, T.K.; Denison, R.F. 2004. Yield increases during the organic transition: improving soil quality or increasing experience? Field Crops Research 86: 255-266.

Polat, E.; Demir, H; Onus, A.N. 2008. Comparison of some yield and quality criteria in organically and conventionally-grown lettuce. African Journal of Biotechnology 7: 1235-1239.

Rinaldi, M.; Vonella, A.V.; Garofalo, P., eds. 2007. Organic fertilization in a "tomato - pea" rotation in southern Italy. p. 310. Proceedings of the $3^{\text {rd }}$ QLIF Congress. Hohenheim, Germany.

Shewfelt, R.L.; Prussia, S.E. 1993. Postharvest Handling: A Systems Approach. Academic Press, San Diego, CA, USA.

Thybo, A.K.; Edelenbos, M.; Christensen, L.P.; Sørensen, J.N; Thorup-Kristensen, K. 2006. Effect of organic growing systems on sensory quality and chemical composition of tomatoes. LWT 39: 835-843.

Türkish Statistics of [TUIK]. 2008. Agricultural statistics. 2008. Available at: http://www.tuik.gov.tr/PreTablo.do?tb_id $=45 \&$ ust_id $=13$ [Accessed Nov. 11, 2008]

Vural, H.; Esiyok, D.; Duman, I. 2000. Vegetable Growing. Ege Univiversity Press, Ýzmir, Turkey.

Woodward, L.; Lampkin, N. 1990. Organic agriculture in the United Kingdom. p.19-29. In: Unwin R, ed. Proceedings of the Symposium on Crop Protection in Organic and Low Input Agriculture. Churchill College, Cambridge, UK.

Received September 12, 2008

Accepted February 25, 2010 